\title{
PENDEKATAN WILAYAH DALAM STUDI ISLAM (Perkembangan Kehidupan Keagamaan Dan Aktivitas Muamalah Masyarakat Minoritas Muslim Di Asia Tenggara)
}

\author{
Evan Hamzah Muchtar ${ }^{1}$ \\ evan.hamzah.m@gmail.com
}

\begin{abstract}
Abstrak
This paper will discuss Islamic studies on religious life and muamalah activities with regional approaches in Southeast Asia, especially in Muslim minority communities in Myanmar, Thailand and the Philippines. The discussion begins with the understanding of Islamic studies, the background of the spread of Islam in Southeast Asia, and the development of muamalah Muslim minority communities in Southeast Asia, especially in Myanmar, Thailand and the Philippines. Their position as a minority influences the development of religious institutions. In the process of national integration launched by the government, Muslim communities face changes in social and political orientation.
\end{abstract}

\section{A. Pendahuluan}

Islam sebagai objek pengkajian dan penelitian ilmiah dapat dilihat dari berbagai dimensi. Diantaranya, dari dimensi Islam sebagai pengamalan, yang berwujud dalam bentuk budaya dan peradaban (Islam as Practice: Culture/Civilization) yang lahir dari, dan dipraktekkan oleh Umat Islam. Pengkajian Islam pada tataran ini dapat dilakukan dengan menggunakan pendekatan sejarah, antropologis, sosiologis, psikologis, fenamenologis, geografis (wilayah), dan lainnya.

Dalam hal keragaman ekspresi sosio-kultural, Islam Asia Tenggara merupakan salah satu ranah budaya Islam (Islam cultural realm) yang berbeda. Salah satu basis kultural dan ciri paling jelas dalam hal ini adalah bahasa Melayu dan tradisi sosiokultural lain. Terbentuknya corak Islam Nusantara atau Asia Tenggara pertama-tama berkaitan dengan kenyataan geografisnya yang jauh dari Arabia. Wilayah Islam Melayu disebut dengan Islamique peripherique (Islam pinggiran), sedangkan wilayah Islam Timur Tengah disebut dengan Islamic core (Islam inti/pusat).

Sejak era 1970-an, perkembangan kehidupan masyarakat muslim di Asia Tenggara dipengaruhi oleh pola pemerintahan dan struktur bernegara yang telah dan sedang berkembang. Munculnya organisasi Islam dan aktivitas keislaman yang ada

\footnotetext{
${ }^{1}$ Dosen Tetap Prodi Perbankan Syariah STAI Asy-Syukriyyah
} 
mencerminkan respons kaum muslim Asia Tenggara terhadap keadaan yang terus berubah dan dinamis. Dinamika seperti ini telah menjadi salah satu ciri menonjol dari Islam di Asia Tenggara. Islam di Asia Tenggara telah menciptakan pandagan dunia yang pluraslis dan terbuka. ${ }^{2}$

Dari segi jumlah penduduk muslim, Asia Tenggara merupakan konsentrasi penduduk muslim terbesar di dunia setelah Asia Selatan, walaupun pada kenyataannya hanya tiga Negara: Brunei, Indonesia dan Malaysia yang memiliki penduduk mayoritas muslim. Filipina, Myanmar dan Thailand dihuni oleh masyarakat muslim dalam jumlah yang signifikan, kendati kecil dari segi presentase. Di Singapura, persentase mereka sekitar 15\% dari jumlah penduduk Negara; sedangkan dalam angka jumlah mereka lebih rendah daripada masyarakat Moro di Filipina. Di Kampuchea, Vietnam dan Laos, masyarakat muslim sebagian besar terdiri dari etnis Cam. Persentase mereka terhadap penduduk keseluruhan tidak besar. Namun jumlah riilnya hampir mencapai satu juta. ${ }^{3}$

Tulisan ini akan membahas tentang studi Islam pada kehidupan beragama dan aktivitas muamalah dengan pendekatan wilayah di Asia Tenggara khususnya pada masyarakat minoritas muslim di Myanmar, Thailand dan Filipina. Pembahasan dimulai dengan pengertian studi islam, latar belakang penyebaran Islam di Asia Tenggara, dan perkembangan muamalah masyarakat minoritas muslim di Asia Tenggara khususnya di Myanmar, Thailand dan Filipina.

\section{B. Pembahasan}

1. Pengertian

Studi wilayah (area studies) terdiri dari dua kata, area dan studi. Area mengandung arti "region of the earth's surfaces", 4 artinya adalah daerah permukaan bumi. Selain itu juga bermakna: luas, daerah kawasan setempat dan bidang. ${ }^{5}$ Sedangkan studi mengandung pengertian "devotion of time and thought to getting knowledge", ${ }^{6}$ artinya pemanfaatan waktu dan pemikiran untuk mendapatkan

\footnotetext{
${ }^{2}$ Taufik Abdullah, et. al., Ensklopedi Tematis Dunia Islam Jilid 6 Dinamika Masa Kini (Jakarta: Ichtiar Baru Van Hoeve, 2002), hlm. 303

${ }^{3}$ Taufik Abdullah, et. al., Ensklopedi ..., hlm. 303

${ }^{4}$ A.S. Hornby, Oxford Advanced Learner's Dictionary (Oxford: Oxford University Press, 1986), hlm. 40

${ }^{5}$ Peter Salim, Webster's New World Dictionary (Jakarta: Modern English Press, t. t.), hlm. 31

${ }^{6}$ A.S. Hornby, Oxford ..., hlm. 859
} 
ilmu pengetahuan. Studi juga mengandung pengertian "something that attracts investigation" yakni sesuatu yang perlu untuk dikaji.

Studies adalah bentuk jamak dari studi, kata ini menunjukkan bahwa kajian yang dilakukan terhadap sebuah wilayah tidak hanya terbatas pada suatu bidang kajian, melainkan terdiri dari berbagai bidang. Secara terminologi studi wilayah adalah pengkajian yang digunakan untuk menjelaskan hasil dari sebuah penelitian tentang suatu masalah menurut wilayah dimana masalah tersebut terjadi. ${ }^{7}$

Studi Islam adalah usaha sadar dan sistematis untuk mengetahui dan memahami serta membahas secara mendalam hal-hal yang berhubungan dengan Agama Islam, baik berhubungan dengan sejarah, ajaran maupun praktek nyata dalam kehidupan. ${ }^{8}$

Dengan demikian yang dimaksud dengan pendekatan wilayah dalam studi Islam adalah suatu pengkajian Islam pada suatu daerah tertentu secara sistematis, artinya bagaimana kondisi Islam yang dipahami oleh masyarakat suatu daerah tertentu, baik pemahaman keislamannya maupun sejauh mana Islam berkembang di wilayah tertentu dan sebagainya. ${ }^{9}$

\section{Latar Belakang Masuknya Islam di Asia Tenggara}

Muhammad saw. adalah Rasul Allah yang terakhir, sebagai penutup dari serangkain Rasul-rasul yang telah diutus oleh-Nya sepanjang sejarah kehidupan manusia di muka bumi ini. Beliau membawa agama samawi yang bersifat universal dan eternal. Dalam arti, bahwa jika Rasul-rasul sebelumnya diutus untuk mendakwahkan ajaran agama samawi kepada lingkungan budaya bangsanya masing-masing, maka Muhammad saw. sebagai Rasul terakhir harus mendakwahkan ajaran agama samawi yang dibawanya kepada lingkungan budaya bangsa-bangsa di dunia dan berlaku sampai akhir zaman. Agama samawi yang dibawa oleh Nabi Muhammad saw. inilah yang selanjutnya disebut dengan agama Islam yang bersifat final, universal dan eternal. ${ }^{10}$

\footnotetext{
${ }^{7}$ Abuddin Nata, Metodologi Studi Islam (Jakarta: Rajawali Press, 1999), hlm. 142

${ }^{8}$ Muhaimin, et. al., Kawasan dan Wawasan Studi Islam (Jakarta: Kencana, 2007), hlm. 1

${ }^{9}$ Samsuddin, Pendekatan Wilayah Dalam Studi Islam, dalam Nawir Yuslem, Metodologi dan Pendekatan Dalam Pengkajian Islam (Bandung: Citapustaka Media, 2013), hlm. 223

${ }^{10}$ Muhaimin, et. al., Kawasan ..., hlm. 26
} 


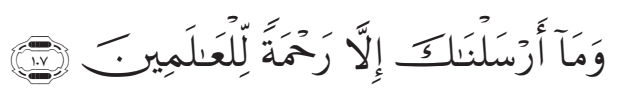

"Dan Tiadalah Kami mengutus kamu, melainkan untuk (menjadi) rahmat bagi semesta alam”.

(Q.S. al-Anbiya': 107)

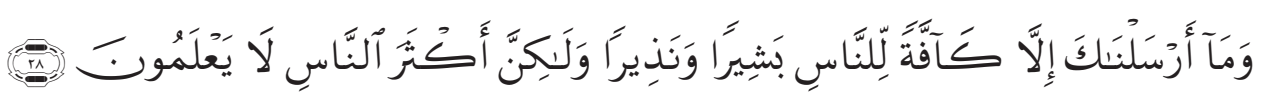

"Dan Kami tidak mengutus kamu, melainkan kepada umat manusia seluruhnya sebagai pembawa berita gembira dan sebagai pemberi peringatan, tetapi kebanyakan manusia tiada mengetahui".

(Q.S. Saba': 28)

Sepanjang hayatnya, Nabi Muhammad saw. telah berhasil mendakwahkan ajaran agama Islam kepada lingkungan budaya bangsa Arab. Kemudian beliau menyerahkan tugas-tugasnya itu kepada para sahabat dan para pengikutnya yang setia dari satu generasi ke generasi berikutnya, dan tugas itu tetap berlaku sampai sekarang hingga akhir zaman. ${ }^{11}$

Geliat gerakan intelektual telah mulai sejak masa Rasulullah dimana beliau mengajak dan mendorong manusia untuk menuntut ilmu. Setelah Perang Badar, Rasulullah mau melepaskan para tawanan perang jika mereka telah mengajarkan baca tulis kepada sepuluh anak Madinah. Bersamaan dengan menyebarnya Islam di berbagai negeri, para non-Arab yang masuk Islam mulai belajar bahasa Arab agar mereka dapat mengenal dasar-dasar agama Islam. Bahasa Arab mulai menyebar dikalangan mereka bersamaan dengan merebaknya belajar baca tulis. Selain itu, mereka juga mempelajari gramatika serta mengkaji hukum-hukum umum yang meliputi pernikahan, talak, muamalah, dan aturan-aturan umum lainnya. ${ }^{12}$

Sejarah telah mencatat keberhasilan para sahabat dalam mengemban tugas dakwah Islamiah ke dalam lingkungan budaya bangsa-bangsa. Dalam waktu relatif

\footnotetext{
${ }^{11}$ Muhaimin, et. al., Kawasan ..., hlm. 27

${ }^{12}$ Muhammad Husain Mahasnah, Pengantar Studi Sejarah Peradaban Islam, Jakarta: Pustaka Al-Kautsar, 2016, hlm. 127
} 
singkat, agama Islam telah berhasil memasuki bangsa-bangsa besar di dunia pada masa itu. Lingkungan budaya bangsa Persi, Yunani, Romawi, India dan Cina telah memasuki agama Islam, bahkan telah dipersatukan dalam satu sistem budaya Islam di bawah naungan kekhalifahan Islam pada masa daulah Bani Umayyah dan Abbasiyah. Pada masa ini agama dan budaya Islam telah mencapai masa kejayaannya, dan Islam telah menunjukkan dinamikanya yang tinggi. Bahkan sistem budaya Islam telah berkembang menjadi sistem budaya yang menguasai dunia global. ${ }^{13}$

Para sahabat menyebar di berbagai daerah untuk mengajar dan membimbing kaum muslimin yang berada di berbagai negeri. Masing-masng sahabat memiliki madrasah yang muridnya dari kalangan tabi'in. para tabi'in memiliki murid dari kalangan tabi' tabi'in. begitu seterusnya hingga peradaban Islam semakin meluas.

Istilah Asia Tenggara yang dimaksud dalam tulisan-tulisan de Graaf, Roff, dan Benda adalah wilayah-wilayah Islam di Indonesia, Malaysia (Semenanjung dan Kalimantan Utara), Patani (Thailand), dan Mindanau (Filipiina Selatan). Asia Tenggara dalam cakupan wilayah seperti itu, juga disamakan pengertiannya dengan Nusantara (Archipelago) yang mencakup wilayah yang sama. ${ }^{14}$

Marcopolo, dalam perjalanannya dari Cina menuju Persia pada tahun 1292, telah mengunjungi delapan kerjaan di Pulau Sumatera. Dari delapan Negara yang dikunjunginya, hanya satu kerajaan yang dianggapnya telah memeluk Islam, yaitu Perlak. Para pedagang muslim mengislamkan Perlak hanya di sekitar perkotaan. Penduduk yang tinggal di pedalaman tetap kafir dan menyembah apa saja yang mereka lihat pada pagi hari.

Adapun mengenai kedatangan Islam ke Asia Tenggara terdapat tiga pendapat. Pertama, pendapat yang mengatakan bahwa Islam datang ke Asia Tenggara langsung dari Arab, atau tepatnya Hadramaut. Pendapat ini pertama-tama dikemukakan oleh Crawfurd (1820), Keyzer (1859), Nieman (1861), de Hollander (1861), dan Veth (1878). Crawfurd menyatakan bahwa Islam yang datang ke Asia Tenggara berasal dari Arab. Keyzer berpendapat bahwa Islam yang datang ke Asia

${ }^{13}$ Muhaimin, et. al., Kawasan ..., hlm. 27

${ }^{14}$ Atang Abd. Hakim \& Jaih Mubarok, Metodologi ..., hlm. 167-171 
Tenggara berasal dari Mesir yang bermahzab Syafi'i. sedangkan Niemann dan de Hollande berpendapat bahwa Islam yang datang ke Asia Tenggara berasal dari Hadramaut karena kesamaan mazhab yang dianut, yaitu mazhab Syafi'i. Disamping itu, Veth berpendapat bahwa Islam dibawa oleh orang-orang Arab tanpa menyebut daerah asalnya. Pendapat yang sama juga dikemukakan oleh Hamka yang menyatakan bahwa Islam datang ke Indonesia langsung dari Arab, bukan melalui India dan bukan pada abad ke-11 tetapi abad ke-7.

Kedua, pendapat yang mengatakan bahwa Islam yang datang ke Asia Tenggara berasal dari India. Pendapat ini pertama kali dikemukakan oleh Pijnapel pada tahun 1872. Berdasarkan hasil penelaahannya, ia berkesimpulan bahwa yang membawa Islam ke Asia Tenggara adalah orang-orang Arab yang bermahzab Syafi'I dari Gujarat dan Malabar di India. Pendapat ini dikembangkan oleh Snouck Hurgronye. Ia menyatakan bahwa para pedagang Kota Pelabuhan di Dakka di India Selatan adalah pembawa Islam ke Asia Tenggara (Sumatera). Pendapat ini kemudian dikembangkan oleh Morrison pada tahun 1951 dengan menunjuk tempat yang pasti di India, yaitu pantai Koromandel sebagai pelabuhan tempat bertolaknya para pedagang Muslim dalam pelayaran mereka menuju Nusantara.

Ketiga, pendapat yang mengatakan bahwa Islam yang datang ke Asia Tenggara berasal dari Benggali (kini Bangladesh). Mengutip pendapat Tomo Pires, Azra mengungkapkan bahwa kebanyakan orang terkemuka di Pasai adalah orangorang Benggali dan keturunannya. Pendapat ini dikemukakan oleh Fatimi. Namun pendapat ini dibantah oleh Drewes yang mengatakan mazhab yang dianut di Benggala adalah mazhab Hanafi, bukan mazhab Syafi'I, seperti yang dianut oleh muslim di nusantara.

Penetrasi Islam di Asia Tenggara secara umum dapat dibagi ke dalam tiga tahap: Pertama, penetrasi dimulai dengan kedatangan Islam dan ditandai dengan kemerosotan dan kehancuran Kerajaan Majapahit pada abad ke-14 dan ke-15. Pada penetrasi tahap pertama, penyebaran Islam masih relatif terbatas di kota-kota pelabuhan. Peran para pedagang dan ulama yang sekaligus guru-guru tarekat beserta murid-muridnya, sangat besar dalam penyebaran Islam. Pada tahap pertama ini, Islam diwarnai dengan tasawuf atau mistik. Meskipun tidak berarti aspek 
hukum terabaikan, dimensi tasawuf tetap unggul dalam tahap Islamisasi ini, setidaknya sampai abad ke-17. Islam mistik atau tasawuf yang datang ke Nusantara dengan segala pemahaman dan penafsirannya - dalam beberapa segi-ternyata cocok dengan latar belakang masyarakat setempat yang dipengaruhi asketisme Hindu-Budha dan sinkretisme kepercayaan lokal. Penyebab lainnya, karena tarekat cenderung toleran terhadap tradisi semacam itu, yang sebenarnya bertentangan dengan praktik unilitarianisme Islam.

Dalam tahap pertama ini, Islam tidak langsung diterima masyarakat pada umumnya. Karena itu, di Jawa, misalnya, sebagian penduduk tetap menganut kepercayaan nenek moyang mereka, atau memeluk agama Islam hanya secara nominal. Keadaan yang hampir sama juga ada di Minangkabau. Sebuah manuskrip tahun 1761 menunjukkan bahwa Minangkabau darek (nama kota) kebanyakan masih menyembah berhala. Meskipun demikian, pada abad ke-18 lembaga-lembaga Islam yang vital seperti meunasah (Aceh), surau (Minangkabau dan Semenanjung Malaya), dan pesantren (Jawa), mulai mapan, walaupun kebanyakan masih tetap merupakan kubu-kubu tasawuf.

Salah satu tradisi belajar yang dikembangkan ketika itu adalah pengembaraan intelektual: guru dan kebanyakan murid-murid menuntut ilmu dan mengembara dari satu surau ke surau lain atau dari satu pesantren ke pesantren lain untuk meningkatkan pengeetahuan keislamannya. Mereka mengembara bukan hanya di sekitar Asia Tenggara, tetapi juga sangat mungkin ke India, Mekah, Madinah, dan Kairo atau tempat-tempat lain di Timur Tengah. Tradisi yang sepeti ini mendorong intensifikasi Islamisasi di kalangan masyarakat Nusantara secara keseluruhan sehingga mendorong Melayu mengalami kecenderungan yang kuat ke arah ortodoksi.

Salah satu perkembangan intelektual yang cukup menarik adalah dimulainya tradisi menulis. Kitab yang ditulis dalam bahasa Melayu diantaranya kitab Shirat al-Mustaqim karya Nuruddin Arraniri (1685) dari Aceh. Kitab ini kemudian diberi syarah oleh Muhammad Arsyad al-Banjari (1710-1812) dari Kalimantan Selatan menjadi kitab Sabil al-Muhtadin. Kitab Sabil al-Muhtadin ini kemudian dibei syarah kembali oleh Daud al-Fatani (1847) dari Thailand dan diberi nama Bughyat al-Thullab. 


\section{Jurnal Asy-Syukriyyah}

Penetrasi Islam kedua dimulai sejak datang dan mapannya kekuatan kolonialis di Asia Tenggara: Belanda berkuasa di Indonesia, Inggris di Semenanjung Malaya, dan Spanyol di Filipina, sampai abad ke-19. Sebagaimana dijelaskan oleh Roff dan Benda, penjajahan kolonial justru mendorong kristalisasi renaisans Islam. Karena kolonialis diidentifikasi sebagai penjajah kafir, akhirnya Islam tampil sebagai satu-satunya wadah yang mampu memberikan identitas diri dan menjadi faktor pemersatu masyarakat pribumi yang terbelah oleh berbagai faktor sosial dan kultural dalam menghadapi penjajah Barat.

Penetrasi Islam ketiga bermula pada awal abad ke-20, ditandai dengan liberisasi kebijakan pemerintah kolonial, terutama Belanda di Indonesia. Karena Kristen sudah terlanjur dihubungkan dengan penjajah, ia sulit dijadikan mekanisme pertahanan diri penduduk Nusantara pada umumnya. Di samping itu, kepercayaan sebagai pemersatu, karena Hindu-Budha hanya berada di pusat kekuasaan Jawa Tengah dan Jawa Timur.

Dari segi geografis muslim di Asia Tenggara dapat dikatakan hidup di bagian peripheral dari jantung Islam di dunia Arab. Mereka tersebar di Negaranegara kepulauan, suatu tipe yang tidak monolitik dengan kompleksitas suku yang menakjubkan. Dalam tingkat tertentu di satu sisi Muslim Asia Tenggara diayomi oleh Islam yang dapat menembus batas-batas negara dan alienasi, di sisi lain dihadapkan pada peraturan kenegaraan yang terkadang menimbulkan pertentangan diantara mondial dan keagamaan. ${ }^{15}$

3. Perkembangan Masyarakat Minoritas Muslim Di Asia Tenggara ${ }^{16}$

Pembahasan mengenai perkembangan masyarakat minoritas muslim di Asia Tenggara akan diarahkan kepada Negara Myanmar, Thailand dan Filipina. Kedudukan mereka sebagai minoritas ikut mempengaruhi perkembangan institusi keagamaan. Dalam proses integrasi nasional yang dilancarkan pemerintah, masyarakat muslim menghadapi perubahan orientasi sosial dan politik.

\footnotetext{
${ }^{15}$ Ahmad Ibrahim, et. al., Readings on Islam in Southeast Asia (Singapura) dalam Syahrin Harahap, Islam \& Modernitas: Dari Teori Modernisasi Hingga Penegakkan Kesalehan Modern (Jakarta: Kencana, 2015), hlm. 256

${ }^{16}$ Taufik Abdullah, et. al., Ensklopedi ..., hlm. 304-317
} 
Dalam bidang politik, masyarakat muslim di Myanmar, Thailand dan Filipina menghadapi persoalan tersendiri. Misalnya, muslim Rohingnya (Myanmar), muslim Pattani (Thailand) dan Moro (Filipina) yang diwilayah mereka sendiri merupakan kelompok mayoritas menentang integrasi total ke dalam Negara. Namun, pemerintah pusat terus berusaha melaksanakan program penyatuan dan integrasi. Dalam bidang sosial, masyarakat muslim dituntut menjadi warga Negara yang beridentitas nasional.

\section{a. Muslim Myanmar}

Masyarakat muslim di Myanmar (Burma) mempunyai akar yang cukup dalam. Pembagian masyarakat muslim di Myanmar dilakukan dengan memperhitungkan faktor etnis. Misalnya, muslim Burma, muslim Rohingnya, muslim keturunan India, muslim Huihui (Pathay) dan Zerbadi. Kemudian pembagian ini juga dapat diterjemahkan ke dalam hubungan dengan pemerintah.

Muslim Rohingnya lebih dikenal dengan perjuangan bersenjata untuk mendapatkan otonomi di wilayah Arakan Utara. Walaupun perjuangan mereka mengalami kemunduran sejak 1961, semangat untuk memperjuangkan tuntutan otonomi masih tetap populer di kalangan Rohingnya. Perlawanan bersenjata, kendati masih berlaku secara sporadis, bukan merupakan pilihan yang menguntungkan di bawah pemerintahan militer yang berkuasa sejak 1961.

Kondisi sosial dan ekonomi yang amat buruk, apalagi di Arakan yang terpencil, telah mengundang masalah. Masyarakat Rohingnya tidak banyak memiliki pilihan kecuali memanfaatkan kesempatan yang ada. Sewaktu mereka tidak mampu menahan berbagai tekanan dan pederitaan muncullah berbagai reaksi.

Reaksi paling menonjol terjadi ketika pemerintah Myanmar berusaha mengisolasi serta membatasi status kewarganegaraan dan hak kependudukan mereka. Kebijakan itu mendorong penduduk Rohingnya hijrah secara besar-besaran ke Bangladesh. Jumlah mereka yang megungsi mencapai sekitar 200.000 orang pada 1978. Mereka tidak hanya melakukan protes terbuka dengan melarikan diri ke perbatasan Bangladesh, tetapi juga tertarik dengan perjuangan bersenjata yang dipertahankan berbagai kelompok mujahid. 
Masyarakat muslim keturunan India sejak kudeta di bawah Jendral Ne Win pada 1962 banyak yang hengkang dari Myanmar terutama para pemodal dan pedagang. Dalam konstelasi kehidupan sosial keagamaan di kalangan muslim Myanmar, masyarakat keturunan ini terlihat dinamis dan penuh inisiatif. Ikatan mereka yang kuat dengan induk institusi keagamaan dan sosial di luar Myanmar mengakibatkan timbulnya perbedaan visi dan pendekatan terhadap Negara, budaya, dan masyarakat Myanmar. Masyarakat keturanan menyebar di pusat pemerintahan, ekonomi serta perdagangan.

Masyarakat Huihui di Myanmar diperkirakan berjumlah 5.000 jiwa. Mereka berprofesi sebagai pedagang dan penyedia jasa di kota di belahan tengah dan utara Myanmar. Dalam hal perkawinan, masyarakat Huihui cenderung untuk memilih pasangan perkawinan dari kelompok Burma yang lain semakin meningkat sejak 1970-an. Hal serupa juga terjadi pada masyarakat muslim Zerbadi (warga lama Myanmar yang memiliki darah campuran India). Mereka semakin terserap kedalam masyarakat Burma yang dominan.

Masyarakat muslim pribumi (Burma) pada awalnya berkembang di pusat kerajaan lama di Lembah Irawadi bagian tengah, di sekitar Mandalay. Diperkirakan mereka merupakan keturunan dari para mubalig dan penduduk awal yang kemudian beranak pinak dengan masyarakat Burma. Kebanyakan dari mereka menekuni usaha pertanian dan perdagangan eceran. Dengan perubahan demografi yang terjadi akibat konflik di Arakan dan migrasi keluar secara besar-besaran di kalangan masyarakat muslim keturunan India, masyarakat muslim Burma dan Zerbadi menjadi kelompok muslim terbesar, disusul dengan Rohingnya dan keturunan India.

b. Muslim Thailand

Pembawa Islam pertama ke Thailand (Pattani) menurut Hikayat Pattani adalah Syekh Said, seorang mubalig dari Pasai, yang berhasil menyembuhkan Raja Pattani bernama Paya Tu Nagpu. Setelah masuk Islam, Paya Tu Nagpu mendapat gelar Sultan Ismail Syah Zilullah Fi al-Alam. Selanjutnya putra dan putrinya juga masuk Islam. Pada masa pemerintahannya putranya yang pertama yaitu Sultan 
Muzaffar Syah, datang seorang mubalig yang bernama Safiuddin untuk menyebarkan Islam lebih lanjut di Pattani.

Masyarakat muslim di Thailand terdiri dari berbagai kelompok sosial dan terdapat di berbagai lokasi geografis. Mereka tersebar di berbagai propinsi di bagian utara, tengah dan selatan. Sebagian besar dari mereka merupakan keturunan Melayu, Cam, Asia Selatan, Indonesia, Huihui dan Persia. Dengan semakin terbukanya hubungan sosial di daerah perkotaan dikarenakan adanya pengaruh dari sistem pendidikan dan budaya modern, membuat semakin banyak diantara mereka yang menikah dengan penduduk Thai.

Muslim Thai kebanyakan tinggal di kota Bangkok dan Chiang Mai. Di Chiang Mai, mayoritas penduduk muslim yang berjumlah sekitar 5.000 jiwa pada awal 1980-an terdiri dari keturunan Huihui dan Asia Selatan (terutama Tamil, Punjabi dan Bengali). Masyarakat muslim setidaknya berjumlah 5\% dari seluruh penduduk Chiang Mai. Mereka kelihatannya telah mengintegrasikan dengan baik sebagai bagian dari penduduk Thailand.

Masyarakat muslim keturunan Pakistan merupakan kelompok terbesar, lebih dari separuh total penduduk muslim di Chiang Mai dan sekitarnya. Mereka pada awalnya merupakan pengusaha pertanian, peternakan, penyembelihan hewan dan perdagangan hewan. Kebanyakan dari mereka menempati pemukiman di Chang-klarn dan Chang-puerk.

Sementara itu masyarakat Huihui merupakan keturunan para pelarian muslim Yunan dari Cina sejak akhir abad ke-19. Mereka menempati dua kawasan perdagangan di Chiang Mai, termasuk Wieng-ping dan San Pah-koy. Masyarakat Huihui kebanyakan menekuni profesi perdagangan dan jasa. Karena memiliki mobilitas yang cukup tinggi, masyarakat Huihui juga menyebar ke berbagai pusat perdagangan di luar Chiang Mai, seperti Propinsi Lamphun dan Chiangrai.

Di Bangkok, jumlah masyarakat muslim mencapai sekitar $8 \%$ dari jumlah penduduk. Selain keturunan Melayu dari Thailand Selatan dan Semenanjung Malaka, terdapat juga masyarakat muslim keturunan Indonesia (1.000-1.500 jiwa), Asia Selatan (5.000-7.500), Iran (1.000-1.200), dan Cam (2.000-3.000). Masyarakat keturunan Melayu yang berjumlah melebihi 250.000 jiwa pada awalnya menempati kawasan bagian timur Bangkok seperti Prakanong, Huamak, 
Bangkapi, Nongjak dan Minburi yang merupakan daerah pertanian dan kawasan kampung.

Mayoritas muslim Thai mengamalkan ajaran Islam mazhab Syafi'i. Sebagai bagian dari negeri yang agama resminya adalah Budha, pengaruh sosial agama ini begitu kuat terhadap kehidupan bermasyarakat muslim Thai. Kebiasaan masyarakat Thai dalam menggunakan azimat, tolak bala, dan kepercayaan terhadap magis juga mempengaruhi mereka. Dengan kondisi seperti ini gerakan pemurnian berkembang sejak awal abad ke-20.

Gerakan pemurnian di Bangkok dipelopori oleh Ahmad Wahab Minangkabau. Pada awalnya ia mendirikan madrasah modern di Tanon Kok, Bangkok Utara. Untuk mengefektifkan kegiatan pembaruan yang dipeloporinya, ia mendirikan organisasi Ansari Sunah. Kebanyakan pengikut dan anggotanya terdiri dari para pedagang dan pegawai di Bangkok. Pengaruh gerakan ini bukan hanya terbatas di Bangkok. Namun, karena konservatisme dan kondisi sosial serta keagamaan masyarakat muslim di luar Bangkok, tema pembaruan yang dikobarkan Ahmad Wahab tidak mendapatkan dukungan luas.

Gerakan pembaruan seakan juga menciptakan pengotakan baru masyarakat muslim menjadi "kaum baru" (khana mai) dan "kaum tua" (khana kau). Khana mai merupakan kelompok pembaru yang menginginkan perubahan kehidupan sosial. Sementara itu Khana kau tidak menuntut perubahan drastis dalam bidang sosial dan ekonomi. Kelompok khana kau terus didekati pemerintah untuk memberikan legitimasi terhadap kebijaksanaan, terutama yang berkaitan dengan kelompok minoritas.

Program pembaruan yang disponsori oleh pemerintah, terutama sejak 1960-an, mempengaruhi berbagai segi kehidupan muslim Pattani. Pada tahun 1961 pondok digalakkan untuk menyukseskan program pembaruan. Sistem pendidikan tradisional, seperti pondok dan madrasah, telah berangsur-angsur didorong pemerintah untuk diubah menjadi sekolah swasta yang mengakomodasikan pelajaran umum dan agama. Pada tahun 1971 pemerintah Thailand membuat peraturan terkait dengan pengoperasian pondok/madrasah termasuk tidak diperbolehkannya membuka pondok baru. Akibatnya, banyak pondok yang berhenti beroperasi atau terpaksa mengikuti perubahan tanpa penerapan serius. 
Selain itu juga tidak dapat bersaing dengan sekolah negeri untuk mempersiapkan murid mengikuti jenjang pendidikan negeri yang lebih tinggi. Begitu juga dalam hal pelajaran agama, lulusannya tidak dapat bersaing dengan lulus pondok tradisional. Faktor ini yang membuat pondok tradisonal semakin popular di Pattani walaupun tidak didukung oleh pemerintah.

Semakin banyaknya lulusan sekolah modern dan madrasah cukup mempengaruhi peranan agam dalam kehidupan generasi muda. Kegiatan dakwah menjadi salah satu akibat perubahan sosial dan ekonomi di lingkungan perkotaan. Dengan semakin terbukanya sarana komunikasi dengan dunia luar, berbagai pendekatan keislaman juga turut berkembang di Pattani.

c. Muslim Filipina

Datangnya Islam ke Filipina berdasarkan Hikayat Sulu disebutkan, bahwa mubalig yang pertama datang ke Sulu adalah Syarif Karim al-Makhdum pada sekitar tahun 1380. Ia tinggal di Ibu Kota lama Sulu yaitu Bhuwansa. Menurut Hikayat Minahasa, pelopor islam yang datang adalah Sayid Abu Bakar dan Syarif Muhammad Kabungsuwan yang berasal dari Sumatera; mereka kemudian memperkenlakan ajaran Islam di Sulu, Mindanao dan Buayan. Para pelopor Islam tersebut selanjutnya melakukan penyebaran lebih luas di kalangan bangsawan dan masyarakat luas sehingga muncul kerajaan Islam di daerah tersebut.

Masyarakat Moro di Filipina Selatan merupakan minorotas yang berjumlah besar dan terkonsentrasi. Jumlah mereka mencapai sekitar 5\% dari seluruh penduduk negara (sekitar 82.841.518 jiwa pada juli 2001 dan sekitar 23\% dari penduduk Filipina Selatan. Mereka telah mengalami proses peminoritasan sejak pertengahan abad ke-19. Dengan semakin gencarnya perluasan militer, politik dan ekonomi dari penguasa Spanyol, Amerika Republik Filipina, pada 1948 hingga 1970-an jumlah masyarakat Moro di Filipina Selatan berkurang separuhnya. Faktor utama penurunan jumlah ini adalah migrasi terencana dan besar-besaran ke Tanah Moro dari bagian utara Filipina. Hal ini mengakibatkan mereka semakin terisolasi.

Upaya pemerintah Amerika Serikat yang kemudian dilanjutkan pemerintah Republik Filipina untuk mengintegrasikan masyarakat Moro melalui akomodasi elite muslim ternyata tidak berhasil. Pada pertengahan 1960-an muncul berbagai 
upaya untuk mengadakan perubahan hingga gagasan untuk memisahkan diri dari Negara Filipina. Muncul tokoh-tokoh muda yang menolak status quo, diantaranya adalah Datu Udtog Matalam dan Nur Misuari yang kemudian mendirikan Moro National Liberation Front (MNLF) atau Front Pembebasan Nasional Moro pada 1969.

Puncak perjuangan ditandai dengan penandatanganan Perjanjian Tripoli antara Manila dan para pemimpin MNLF pada 1976. Berdasarkan perjanjian tersebut, masyarakat Moro akan mendapatkan hak otonomi penuh atas 13 provinsi di Filipina Selatan. Profinsi tersebut yakni: Basilian, Sulu, Tawi-tawi, Zamboanga del Sur, Zamboanga del Norte, North Cotabato, South Cotabato, Manguindanao, Sultan Kudarat, Lanao del Norte, Lanao del Sur, Davao del Sur dan Palawan.

Pada tahun 1981 pemerintah membentuk Kementerian Urusan Islam (KUI) sebagai wadah untuk masyarakat Moro dalam melakukan integrasi dengan membuka kesempatan kepada masyarakat Moro untuk berperan aktif dalam pembangunan dan kehidupan bernegara dapat sejajar dengan masyarakat Filipina lainnya. Dengan adanya pergantian kepemimpinan di Negara Filipina juga berdampak kepada perkembangan sosial dan keagamaan di masyarakat Moro.

Pembangunan ekonomi masih belum menyentuh banyak kehidupan mayoritas masyarakat Moro. Bagaimanapun, perluasan penyediaan fasilitas pendidikan, layanan hukum, dan berbagai aspek kesejahteraan sosial yang lain telah sedikit mengangkat taraf kehidupan masyarakat. Juga adanya penyediaan kesempatan yang lebih besar kepada masyarakat muslim untuk mengekspresikan nilai budaya dan keagamaan mereka telah mengurangi jurang antara masyarakat muslim dan non-muslim. Pembukaan universitas negeri di berbagai kota di Filipina Selatan mendorong semakin banyaknya jumlah mahasiswa muslim.

Masyarakat muslim Moro terus menunjukkan dinamika beragama dan bermasyarakat, kendati dalam situasi yang tidak menentu. Mereka terus berupaya meningkatkan usaha pendidikan. Hubungan dengan dunia Islam dan gerakan dakwah internasional maupun regional juga terus dikembangkan. Umpamanya, sejak tahun 1980-an pengaruh gerakan Jamaah Tablig di kalangan masyarakat Moro terutama yang tinggal di perkotaan semakin meningkat. Begitu juga dengan peningkatan berbagai segi kehidupan sosial. 


\section{Jurnal Asy-Syukriyyah}

\section{Kesimpulan}

Kajian yang ada sejauh ini dan lebih populer terhadap masyarakat minoritas muslim di Asia Tenggara khususnya di Myanmar, Thailand dan Filipina lebih difokuskan kepada aspek politik, konflik, pergolakan dan kemanusiaan. Hal ini sangatlah wajar dengan semakin terbukanya informasi komunikasi dan kuatnya penggiat Hak Asasi Manusia.

Kedudukan mereka sebagai minoritas juga ikut mempengaruhi perkembangan institusi keagamaan. Dengan demikian ekspresi keagamaan yang bersifat publik menjadi agak berlainan dengan yang ada pada masyarakat muslim di wilayah Asia Tenggara lainnya. Semangat keislaman yang tumbuh berkembang menjadi sumber harapan dan tumpuan akan terciptanya tatanan Islam yang maju.

Dengan disusunnya tulisan ini diharapkan dapat menambah pengetahuan tentang perkembangan kehidupan keagaaman serta aktivitas muamalah masyarakat minoritas muslim di Asia Tenggara dari pendekatan kawasan. 


\section{DAFTAR PUSTAKA}

Abuddin Nata, Metodologi Studi Islam, Jakarta: Raja Grafindo Persada, 2006

Amin Abdullah, Studi Agama Normativitas atau Historitas?, Yogyakarta: Pustaka Pelajar, 1996

A.S. Hornby, Oxford Advanced Learner's Dictionary, Oxford: Oxford University Press, 1986

Atang Abd. Hakim \& Jaih Mubarok, Metodologi Studi Islam, Bandung: Remaja Rosdakarya, 2000

Muhammad Husain Mahasnah, Pengantar Studi Sejarah Peradaban Islam, Jakarta: Pustaka Al-Kautsar, 2016

Muhaimin, et. al., Kawasan dan Wawasan Studi Islam, Jakarta: Kencana, 2007

Nawir Yuslem, Metodologi dan Pendekatan Dalam Pengkajian Islam, Bandung: Citapustaka Media, 2013

Peter Salim. Webster's New World Dictionary, Jakarta: Modern English Press, t. t.

Syahrin Harahap, Islam \& Modernitas: Dari Teori Modernisasi Hingga Penegakkan Kesalehan Modern, Jakarta: Kencana, 2015

Taufik Abdullah, et. al., Ensiklopedi Tematis Dunia Islam, Jakarta: Ichtiar Baru Van Hoeve, 2002 